\title{
Examination of Stress States and Lifestyle Habits of Academic and Administrative Personnel Holding Office at Universities
}

\author{
Levent $\operatorname{Var}^{1} \&$ Ahmet Dinç ${ }^{2}$ \\ ${ }^{1}$ School of Physical Education and Sports, University of Kirsehir Ahi Evran, Kirsehir, Turkey \\ ${ }^{2}$ School of Physical Education and Sports, University of Iğdır, Iğdır, Turkey \\ Correspondence: Levent Var, School of Physical Education and Sports, University of Kirsehir Ahi Evran, Kirsehir, \\ Turkey. E-mail: levent.var@ahievran.edu.tr
}

Received: November 6, 2018

Accepted: November 20, 2018

Online Published: December 3, 2018

doi:10.5430/ijhe.v7n6p36

URL: https://doi.org/10.5430/ijhe.v7n6p36

\begin{abstract}
The purpose of this research is to examine the relation between the stresses and some lifestyle habits of academic and administrative personnel holding office at Ahi Evran University. 368 personnel in total as being 252 academic and 116 administrative personnel working holding office at Ahi Evran University had participated in this study. In the study, "Health - Exercise and Physical Activity Consciousness Level" questionnaire, developed by Dolasir Tuncel and Tuncel (2009), had been used as data collection tool. SPSS 22,0 packaged software had been used in the statistical analysis of data obtained, and the results had been evaluated at significance level of $p<0,05$. As the result of the research, by the comparison of states of regular exercise and being stressful among the academic and administrative personnel, significance had been determined at a level of $.000(\mathrm{p}<0.001)$ for regular exercise, and of .021 ( $\mathrm{p}<0.05)$ for being stressful. Moreover, when the relation among frequent tension, stressful workplace environment, alcohol consumption, regular exercise and smoking of academic and administrative personnel, a relation at high level in positive direction had been determined between frequent tension and stressful workplace environment $(\mathrm{r}=, 723, \mathrm{p}<0.001)$, a relation at very low level in positive direction had been determined between frequent tension and alcohol consumption $(\mathrm{r}=, 124, \mathrm{p}<0.001)$, and a relation at low level in positive direction had been determined between smoking and alcohol consumption $(\mathrm{r}=, 422, \mathrm{p}<0.001)$. Thus, it is being observed that the stress states of academic and administrative personnel holding office at Ahi Evran University are being affected depending on the workplace environment, and that the alcohol consumption of the personnel is increasing as the cigarette consumption increases.
\end{abstract}

Keywords: academic personnel, administrative personnel, stress, cigarette, alcohol, exercise

\section{Introduction}

Stress, which is including the character of the individual, which is being defined as the relation between the individual and environment and the effect of environmental incidents on the individuals (Lazarus \& Folkman, 1984), which suddenly appears in an incident or in a condition that the individual encounters at an moment (Rowshan, 2003), often arises in case of an imbalance present in the individuals and in the variables system relevant to their environment, and only this imbalance condition causes changes in the normal (balanced) psychological happiness levels of the people (Hart \& Cooper, 2009).

According to Selye (1974), no matter what the cause is, there is a physical reaction that the individual -being exposed to the effect of stressors- manifests. This reaction is resistance of organism against the impairment of physiological balance (Cleaver \& Eisenhart, 1982). The individual's attitude, belief and expectations against stress cover the individual's stress evaluation process. The reaction given against stress is in the form of 'fight or run away'. And the state arising as the result of reaction shown against stress constitutes the result of stress (Rowshan, 2003). The psychological, physiological or behavioral stress reactions that the individual being exposed to the effect of various stressors will manifest are able to give rise to the consequence of her/him being exposed to various problems within a specific time frame depending on the frequency and intensity of stress. Physiological disorders such as migraine, hypertension, allergies, ulcer, diarrhea, constipation, cardiac diseases, diabetes, cancer, fatness; various psychological disorders such as family problems, insomnia, depression, indicator of exhaustion; and mental or behavioral disorders such as cigarette and alcohol consumption, making accidents, violence and unwillingness are 
able to arise as the result of negative reactions of the body to stress. Thus, many problems such as impairment of human's health, decrease of productivity of working, inability of enjoying life, and especially alienation from emotional relations with the immediate vicinity are able to arise (Cleaver \& Einsenhart, 1982).

If the condition giving rise to stress continues, our emotions may turn to anxiety, anger, violence, dissatisfaction and depression depending on whether our efforts of overcoming stress become successful or not (Atkinson, Atkinson, Smith, \& Bem, 1999). The individual, besides these emotional reactions, may encounter problems such as impairment of concentration, difficulty in making decisions, forgetfulness, dysmnesia, excessive fantasizing, idea myopia, loss of sense of humor, low productivity, decrease in work quality, increase in errors, weakness in reasoning (Braham, 1998).

High level of stress had been found to be related with starting the consumption of cigarettes, and continuing the consumption of cigarettes. In some studies, it had been revealed that smoking behavior in adolescence is able to start for overcoming stressful life events (Koval \& Pederson, 1999). In retrospective statements regarding life events, it had been found that the smoking individuals had informed more stressful life events compared to non-smokers (Kassel, Stroud \& Paronis, 2003). Moreover, there is a negative relation between quitting smoking and stress and stressful life events (Siqueira, Diab, Bodian, \& Rolnitzky, 2000). Coping may be defined as a range of behaviors and attitudes that the individual uses for conciliation of compeller external and internal demands. Effective coping is able to decrease the risk of smoking by decreasing the effects of stress (Sussman et al., 1993). In some studies, the smoking behavior had been defined as a mechanism of overcoming stress (Liu, 2003). High stress that the people experience is able to cause habits such as cigarette and alcohol consumption, and thus it is able to harm the human health.

It is being known that meditation, that leaves the individual to the management of her/his own mind in order to move away from her/his mental concerns, stress, tension and illusions by aiming only physical and spiritual relaxation, is a significant leisure time practice in coping with stress (Pehlivan, 1995; Cleaver \& Eisenhart, 1982).

The human, often facing sources of stress within the tempo of today's modern life, is tending towards activities having physical and mental characteristics -by which s/he can have a good time- as well as involving in behavior which are harmful for health such as alcohol and cigarette consumption in order to cope with stress.

It is being known that deaths due to "immobility", which is one of the main problems that people faces, and cardiac, vein and circulation diseases -arising as the result of that- are increasing (Uitenbroek, 1993). The researches are revealing that the people are easily being affected from psycho-social stress sources by immobility, in other words by slow living, and by organic resistance losses as a result of that (Akgün, 1994).

In parallel with socio-cultural and economic changes arising especially in recent years, the affection of people for health, the development of new body consciousness, intentions of taking pleasure and enjoying have increased the tendency to leisure time activities (Uitenbroek, 1993). By regular sportive activities, the people are able to have a strong body. All systems of the body, working muscles, heart, hormones, metabolic reactions and sensitivity of central nervous system are being strengthened through sportive stimulations. Reaching the relaxation phase is important for being able to decrease the reaction against stress (Cleaver \& Eisenhart, 1982).

\section{Method}

\subsection{Research Group and Data Collection}

368 personnel in total as being 252 academics and 116 administrative personnel working holding office at Ahi Evran University in Kırşehir had participated in this study. In the study, "Health - Exercise and Physical Activity Consciousness Level" questionnaire, developed by Dolasır Tuncel and Tuncel (2009) had been used as data collection tool. The $1^{\text {st }}$ section of the questionnaire consists of 39 questions formed in order to determine the personal information and the habit relevant to healthy lifestyle. The part of 'means of coping with stress' in this section had enabled the collection of basic data of this study.

\subsection{Statistical Analysis}

SPSS 22,0 packaged software had been used in the statistical analysis of data obtained, and the results had been evaluated at significance level of $p<0,05$. The number of total participants of research is 368 as being 252 academic personnel, and 116 administrative personnel. Normality test had been applied in order to determine whether the data is conforming to normal distribution or not, and the distribution had been found to be normal. For this reason, parametric test had been applied on the variables. Descriptive statistics had been applied for descriptive statistics 
(Table 1), Independent - Sample T test had been applied for paired comparisons (Table 2), and Pearson Correlation had been applied for multiple comparisons (Table 3, Table 4, Table 5).

\section{Findings}

Table 1. The demographic attributes of the subjects participating in the research

\begin{tabular}{llllll}
\hline & & \multicolumn{2}{l}{ Academic Personnel } & \multicolumn{2}{l}{ Administrative Personnel } \\
\hline \multirow{2}{*}{ Sex } & f & $\%$ & f & $\%$ \\
& Female & 72 & 28,6 & 84 & 60,9 \\
& Male & 180 & 71,4 & 54 & 39,1 \\
\multirow{2}{*}{ Age } & $20-30$ & 43 & 17,1 & 21 & 15,2 \\
& $31-40$ & 147 & 58,3 & 66 & 47,8 \\
& $41-50$ & 46 & 18,3 & 33 & 23,9 \\
& 51 and over & 16 & 6,3 & 18 & 13,0 \\
\multirow{3}{*}{ Marital Status } & Married & 148 & 58,7 & 120 & 87,0 \\
& Single & 98 & 38,9 & 18 & 13,0 \\
& Widower & 6 & 2,4 & - & - \\
\hline
\end{tabular}

252 academic and 116 administrative personnel participated in the research. The demographic attributes of the subjects participating in the research had been completed by $58.3 \%$ of the academic personnel, by $47.8 \%$ of administrative personnel who had an average age of $31-40.58 .7 \%$ of the academic personnel participating in the research are married, and $38.9 \%$ of them are single, and $2.4 \%$ of them are widower, and $87 \%$ of the administrative personnel participating in the research are married, and $13 \%$ of them are single.

Table 2. Comparison of regular exercise and states of being stressful between academic and administrative personnel

\begin{tabular}{llllll}
\hline & Profession & $\mathrm{N}$ & $\mathrm{x} \pm \mathrm{sd}$ & $\mathrm{t}$ & $\mathrm{p}$ \\
\hline \multirow{2}{*}{ Regular exercise } & Academic personnel & 252 & $1,57 \pm, 56$ & & \\
& $\begin{array}{l}\text { Administrative } \\
\text { personnel }\end{array}$ & 116 & $1,81 \pm, 38$ & $-4,114$ &, $000^{* * *}$ \\
& Academic personnel & 252 & $1,35 \pm, 58$ & & \\
\hline \multirow{2}{*}{ Being stressful } & $\begin{array}{l}\text { Administrative } \\
\text { personnel }\end{array}$ & 116 & $1,50 \pm, 58$ & $-2,312$ &, $021^{*}$ \\
& & & & &
\end{tabular}

In Table 2, by the comparison of states of regular exercise and being stressful among the academic and administrative personnel, significance had been determined at a level of $.000(p<0.001)$ for regular exercise, and of $.021(\mathrm{p}<0.05)$ for being stressful. 
Table 3. Relation among frequent tension, stressful workplace environment, alcohol consumption, regular exercise and cigarette consumption of academic and administrative personnel

\begin{tabular}{|c|c|c|c|c|c|}
\hline Academic and Administrative P. & & Frequent Tension & $\begin{array}{l}\text { Stressful } \\
\text { Workplace } \\
\text { Environment }\end{array}$ & $\begin{array}{l}\text { Alcohol } \\
\text { Consumption }\end{array}$ & Regular Exercise \\
\hline \multirow{2}{*}{$\begin{array}{l}\text { Stressful workplace } \\
\text { environment }\end{array}$} & $\mathrm{r}$ &, $723^{* * * * *}$ & & & \\
\hline & $\mathrm{p}$ &, 000 & & & \\
\hline \multirow{2}{*}{ Alcohol consumption } & $\mathrm{r}$ &, $124^{*}$ & 071 & & \\
\hline & $\mathrm{p}$ & ,018 &, 177 & & \\
\hline \multirow{2}{*}{ Regular exercise } & $\mathrm{r}$ &, 100 &, 051 & ,015 & \\
\hline & $\mathrm{p}$ &, 056 &, 331 &, 770 & \\
\hline \multirow{2}{*}{ Cigarette consumption } & $\mathrm{r}$ & ,011 &,- 004 & $422^{* * *}$ &,- 008 \\
\hline & $\mathrm{p}$ & 838 & ,934 &, 000 &, 881 \\
\hline
\end{tabular}

In Table 3, the relation among frequent tension, stressful workplace environment, alcohol consumption, regular exercise and cigarette consumption of academic and administrative personnel has been provided (correlation Pearson). As a result of the analysis made,

High level of relation in positive direction had been determined between state of frequent tension and stressful workplace environment $(\mathrm{r}=.723$, $\mathrm{p}<0.001)$,

Very low level of relation in positive direction had been determined between state of frequent tension and alcohol consumption $(\mathrm{r}=.124, \mathrm{p}<0.001)$,

Low level of relation in positive direction had been determined between consumption of alcohol and cigarette $(\mathrm{r}=.422, \mathrm{p}<0.001)$.

Table 4. Relation among frequent tension, stressful workplace environment, alcohol consumption, regular exercise and cigarette consumption of academic personnel

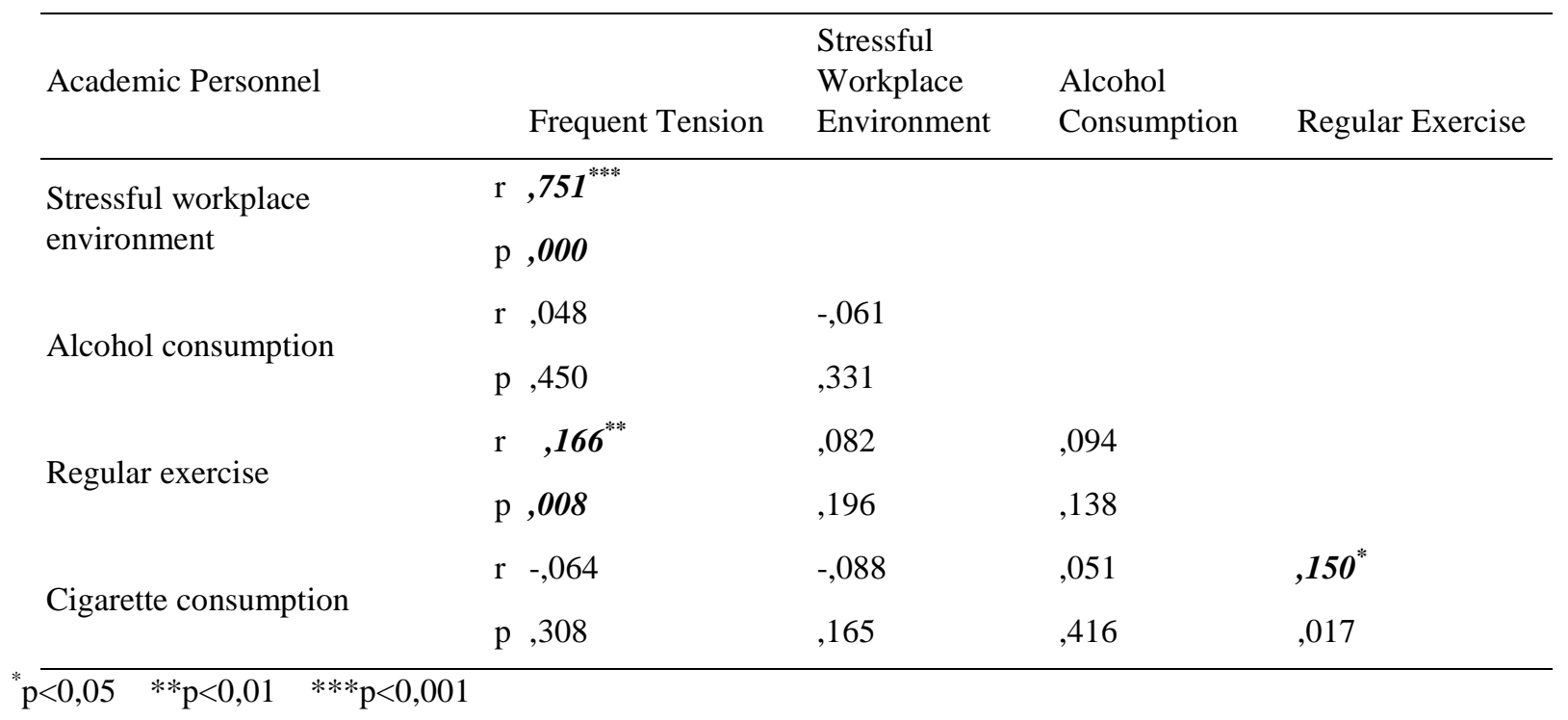


In Table 4, the relation among frequent tension, stressful workplace environment, alcohol consumption, regular exercise and cigarette consumption of academic personnel has been provided (correlation - Pearson). As the result of the analysis made,

High level of relation in positive direction had been determined between state of frequent tension and stressful workplace environment $(\mathrm{r}=.751, \mathrm{p}<0.001)$,

Very low level of relation in positive direction had been determined between regular exercise and state of frequent tension $(\mathrm{r}=.166, \mathrm{p}<0.01)$

Very low level of relation in positive direction had been determined between cigarette consumption and regular exercise $(\mathrm{r}=.150, \mathrm{p}<0.05)$.

Table 5. Relation among frequent tension, stressful workplace environment, alcohol consumption, regular exercise and cigarette consumption of administrative personnel

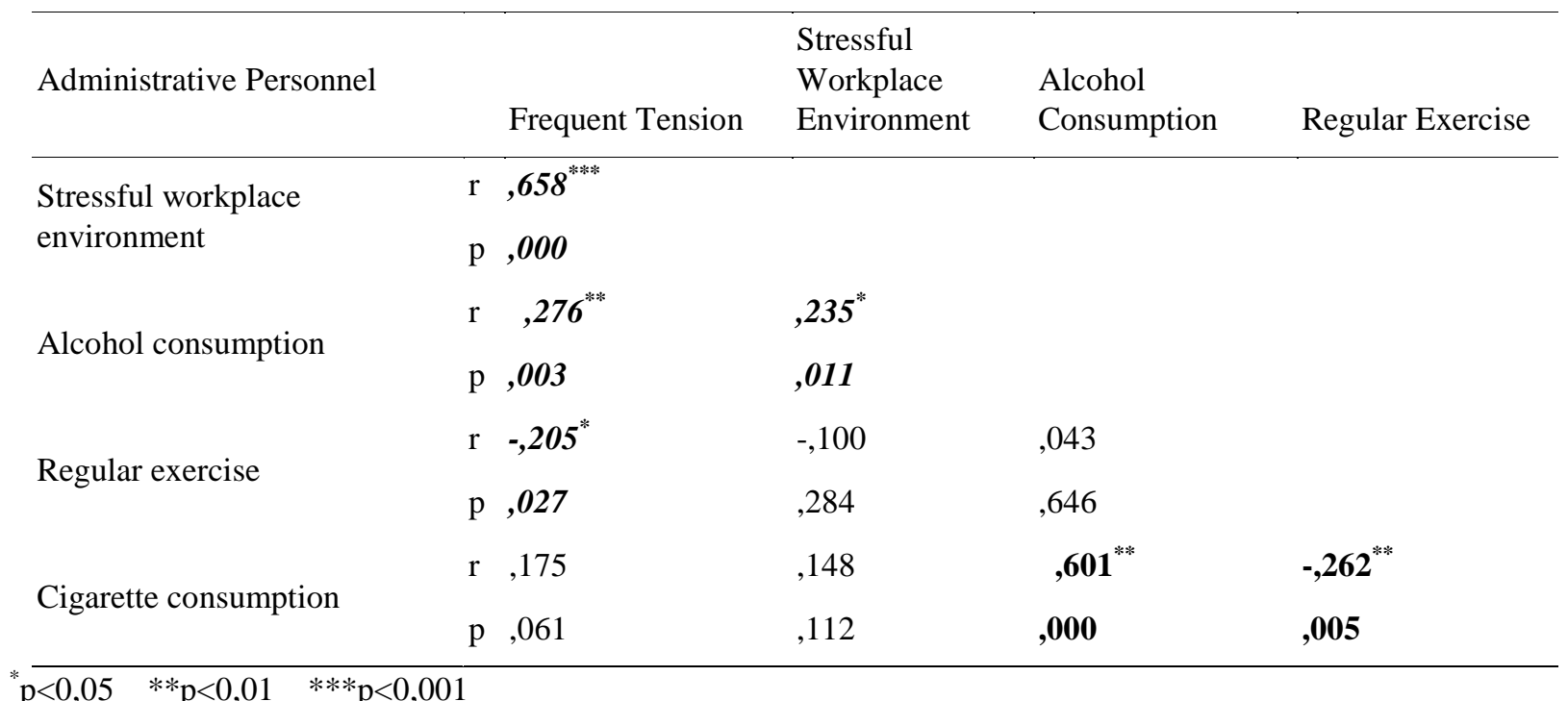

In Table 5, the relation among frequent tension, stressful workplace environment, alcohol consumption, regular exercise and cigarette consumption of administrative personnel has been provided (correlation - Pearson). As the result of the analysis made,

Medium level of relation in positive direction had been determined between state of frequent tension and stressful workplace environment $(\mathrm{r}=.658, \mathrm{p}<0.001)$,

Low level of relation in positive direction had been determined between state of frequent tension and alcohol consumption $(\mathrm{r}=.276, \mathrm{p}<0.01)$,

Very low level of relation in negative direction had been determined between regular exercise and state of frequent tension $(\mathrm{r}=-.205, \mathrm{p}<0.05)$,

Very low level of relation in positive direction had been determined between stressful workplace environment and alcohol consumption $(\mathrm{r}=, 235, \mathrm{p}<0.05)$,

Medium level of relation in positive direction had been determined between consumption of alcohol and cigarette $(\mathrm{r}=.601, \mathrm{p}<0.01)$,

Low level of relation in negative direction had been determined between cigarette consumption and regular exercise $(\mathrm{r}=-.262, \mathrm{p}<0.01)$.

\section{Result and Discussion}

According to the results of the research performed, when the regular exercise and state of being stressful among academic and administrative personnel were examined, it had been observed that the administrative personnel were more stressful compared to administrative personnel, and that they were doing more regular exercise. By this 
condition, it can be said that the need of administrative personnel for doing exercise is more than the academic personnel as the administrative personnel are more stressful.

It had been observed that the state of frequent tension of academic personnel being under stressful workplace environment is increasing. According to this result, it can be said that workplace environment is affecting the state of being stressful.

It had been observed that state of frequent tension of academic personnel -doing regular exercise- is increasing as their states of doing regular exercise increases. Moreover, it had been observed that the state of doing regular exercise of academic personnel is increasing as their cigarette consumption increases. When the literature is considered, it has been determined that these findings are opposite to the findings of many researches. Qualitative study may be performed on the research's group in order to determine the causes of this condition.

It had been observed that state of frequent tension of administrative personnel is decreasing as their state doing regular exercise increases, and that their cigarette consumption is decreasing as their state of doing regular exercise increases. According to these results, it can be said that doing regular exercise has positive effect on administrative personnel.

It had been observed that alcohol cigarette of administrative personnel is increasing as their states of frequent tension and stressful workplace environment increase. According to these results, it can be said that state of tension and stress may push the individuals to consumption of alcohol.

In order to be able to live in a health manner, they are primarily required to find the ways of coping with stress and its effects. It seems obligatory to make very good use of especially the leisure times with various events that ensure physical and mental relaxation, and that will be able to make them ready for working and living. First it is required to eliminate by these events the problem of immobility which arises by modern life, and which may be a significant source of stress (Karaküçük \& Başaran, 1996).

Various lifestyle factors are associated with the increase of paralysis risk. These negative factors are lack of doing exercise, alcohol consumption, incorrect diet, obesity, smoking, and use of medicines. Excessive alcohol consumption, smoking and lack of doing exercise are increasing the risk of cardiovascular diseases and paralysis (Boden-Albala \& Sacco, 2000).

The studies indicated below are showing the relations of stress, cigarette and alcohol consumption and exercise in different groups as similar to this study.

Siqueira, Diab, Bodian, \& Rolnitzky (2000) had found that smokers experience higher level of stress compared to one who had just tried smoking, and who are not smoking. The researches had revealed that the ones quitting smoking are generally less stressful compared to the smokers, and that their levels of stress is definitely lower than the smokers.

Likewise, McKee, Maciejewski, Falba, \& Mazure (1998) are specifying by their study that smoking behaviors of parents and friends are significantly affecting the cigarette use of adolescents. Moreover, in the referred study, it is being emphasized that the main case of cigarette use is the pleasure taken from this behavior, that overcoming stress, effect of friends, wondering and social norms are following it, and that especially for the male participants, the only reason of cigarette use is pressure of friends perceived in the direction of smoking.

In the study of $\mathrm{Ng}$ and Jeffrey (2003) the relation among stress - observed in 110 working adults- and fat intake, exercise, alcohol and cigarette habits had been examined. As the result of the research, it had been observed that the stress levels of people who have dietary habit of consuming high fat, who lack in doing exercise and who smoke are higher. In addition, it had been observed that alcohol consumption is not associated with stress.

Steptoe, Wardle, Pollard, Canaan, Davies, (1996) in their study in which the had considered the relation among cigarette and alcohol consumption and physical exercise level, and stress, social support and health related habits of 180 university students, they had divided the students to two groups as being the group being under the stress of exam and control group. In the group being under the stress of exam, $54.7 \%$ increase had been observed in cigarette alcohol. Moreover, it had been observed that the alcohol consumption of students with low social support is higher. In addition, it had been specified that physical activity was decreasing in the group being under the stress of exam.

In the research performed by Yokoyama et al. (2009) at clinic of Tokyo, the relation of headaches and stress with alcohol consumption, exercise and sleep had been considered through a questionnaire applied during the health check-ups of 12,988 individuals. It had been observed that headache is increasing due to stress level both among 
women and men. Moreover, it had been observed that excessive alcohol consumption and lack of exercise are increasing headache problems both among women and men.

In the study of Kang, Sung, \& Kim (2010) a research grouping the lifestyle risks of people living in Korea had been performed. When high lifestyle risks both among men and women were examined, it had been observed that smoking and excessive alcohol consumption are together, and following that is coming smoking, excessive alcohol consumption and lack of doing exercise. Moreover, it had been observed that unhealthy life among men is more at the age range of 20-64, and that the unmarried women between ages 35-46 have more unhealthy lifestyle habits.

These studies performed relevant to stress, smoking and exercise are supporting this study in terms of smoking due to stress. In other words, as observed both in the studies performed and, in our study, it is being observed that the stress level, alcohol consumption, smoking and exercise observed among people are affecting each other.

In the study of Tuncel, Tuncel, Yüksel, \& Mavi Var (2016) the lifestyle habits of academic and administrative personnel had been examined as similar to our study. As the result of the study, when the stress states of the personnel were examined, $69.9 \%$ of them had specified that they deem their job stressful. The rate of the ones deeming their job stressful is very high and the rate of ones frequently feeling anxious and tense had been determined as $62.3 \%$. When the results relevant to computer/TV habits, exercise habits and stress states (69.9\%) were examined, it had been specified that improvement of healthy lifestyle habits are required. According to the study performed by Cihan \& Araç Ilgar, (2018) it is possible to increase the life habit of people by directing the interest and curiosity to sports and sports activities.

According to the study performed by Sundquist, Qvist, Johansson, \& Sundquist (2005) it had been concluded that coronary heart diseases of women and men doing physical activity for at least 2 time a week is $41 \%$ less compared to ones not doing physical activity.

When the above researches were examined, it had been observed that stress is increasing negative states among people such as cigarette and alcohol consumption, weight gain, and immobility. However, doing regular exercise as keeping away from cigarette, alcohol and stress are very important factors for healthy and quality life. It is being clearly observed from the researches performed that regular exercise habit is decreasing stress among people and providing healthier life. As observed in this study, the states of stress of working people are being affected depending on their workplace environments. In addition, it is being observed that working people are unable to do regular exercise, and that cigarette and alcohol consumption is affecting each other.

\section{References}

Akgün, N. (1994). "Yaşam Boyu Spor Nedir? Ne değildir?", (Ed. Y.Aköz); Türkiye ve Olimpiyat Sempozyumu $17-$ 18 Kasım 1994, İTÜ Beden Eğitimi Bölümü Yayını, İstanbul.

Atkinson, R. Atkinson, R., Smith, E., \& Bem, D. (1999). Psikolojiye Giriş, (Trans. Y. Alogan), Arkadaş Yayınevi, Ankara.

Boden- Albala, B,. \& Sacco, R.L. (2000). Lifestyle factors and stroke risk: Exercise, alcohol, diet, obesity, smoking, drug use, and stress. Current Atherosclerosis Reports, 2(2), 160-166. https://doi.org/10.1007/s11883-000-0111-3

Braham, B. J. (1998). Stres yönetimi. Ateş Altında Sakin Kalabilmek. (Trans. V.G. Diker). Hayat Yayınları, 3.ed., İstanbul.

Cihan, B. B., Araç Ilgar, E. (2018). Determining the curiosity level of high school students who do sports and who do not (sedentary). Ahi Evran University Kirşehir Education Faculty Journal, 19(2), 1649-1660. https://doi.org/10.29299/kefad.2018.19.02.016

Cleaver, V., \& Eisenhart, H. (1982). Stress reduction through effective use of leisure. Journal of Physical Education, Recreation \& Dance, 53(8), 33-34. https://doi.org/10.1080/07303084.1982.10631168.

Dolaşır Tuncel, S. \& Tuncel, F. (2009). Determining the health-exercise/physical activity levels of university students. The Journal of Physical Education and Sport Sciences of Celal Bayar University, 4(1), 51-58.

Hart, P., Cooper, C. (2009). "İş Yerinde Stres: Daha Bütünleştirilmiş Bir Çevreye Doğru”, Endüstri, İş ve Örgüt Psikolojisi El Kitabı 2. Cilt, Ed. Neil Anderson, (Trans. H.K. Sinangil), Literatür Yayıncıllk, İstanbul.

Kang, K., Sung, J., \& Kim, C.Y. (2010). High risk groups in health behavior defined by clustering of smoking, alcohol, and exercise habits: National Heath and Nutrition Examination Survey. Journal of Preventive Medicine and Public Health, 43(1), 73-83. https://doi.org/10.3961/jpmph.2010.43.1.73 
Karaküçük, S. \& Başaran, Z. (1996). Stresle başa çıkmada rekreasyon faktörü. Bed. Eğt. Spor Bil. Spor Bil. Der. I, 4 (1), $55-64$.

Kassel, J.,D., Stroud, L.R., \& Paronis, C.A. (2003). Smoking, stress, and negative affect: Correlation, causation, and context across stages of smoking. Psychological Bulletin, 129(2), 270-304. https://doi.org/ 10.1037/0033-2909.129.2.270

Koval, J.J., \& Pederson, L.L. (1999). Stress-coping and other psychosocial risk factors: a model for smoking in grade 6 students. Addictive Behaviors, 24 (2), 207-18. https://doi.org/ 10.1016/S0306-4603(98)00037-9

Lazarus, R.S., \& Folkman. S. (1984). Stress, appraisal and coping. Springer Publishing Company, New York.

Liu, X. (2003). Cigarette Smoking, Life Stress, and Behavioral Problems in Chinese Adolescents. J Adolescent Health, 33(3), 189-192. https://doi.org/10.1016/S1054-139X(03)00020-X

McKee, S.A., Maciejewski P.K., Falba, T., \& Mazure, C.M. (1998). Sex differences in the effects of stressful life events on changes in smoking status. Addiction, 98(6), 847-55. https://doi.org/10.1046/j.1360-0443.2003.00408.x

Ng, D.M., \& Jeffery, R.W. (2003). Relationships between perceived stress and health behaviors in a sample of working adults. Health Psychology, 22(6), 638-642. https://doi.org/10.1037/0278-6133.22.6.638

Pehlivan, I. (1995). Yönetimde stres kaynakları. Pegem A Yayıncılık, Ankara.

Rowshan, A. (2003). Stres Yönetimi, Sistem Yayıncıllk. 2.ed., İstanbul.

Selye, H. (1974). Stress without distress. New york, 26-39.

Siqueira, L., Diab, M., Bodian, C., \& Rolnitzky, L. (2000). Adolescents Becoming Smokers: The Roles of Stress and Coping Methods. J Adolescent Health, 27(6), 399-408. https://doi.org/10.1016/S1054-139X(00)001671

Steptoe, A., Wardle, J., Pollard, T.M., Canaan, L. \& Davies, J.G. (1996). Stress, social support and Health-related behavior: A study of smoking, alcohol consumption and physical exercise. Journal of Psychosomatic Research, 4l(2), 171-180. https://doi.org/10.1016/0022-3999(96)00095-5.

Sundquist, K., Qvist, J., Johansson, S.E., \& Sundquist, J. (2005). The long-term effect of physical activity on incidence of coronary heart disease: A 12-year follow-up study, Preventive Medicine, 41(1), 219-225. https://doi.org/10.1016/j.ypmed.2004.09.043

Sussman, S., Brannon, B.R., Dent, C.W., Hansen, W.B., Johnson, C.A., \& Flay, B.R. (1993). Relations of coping effort, coping strategies, perceived stress, and cigarette smoking among adolescents. Int J Addict, 28(7), 599-612. https://doi.org/10.3109/1082608930903965

Tuncel, F., Tuncel S., Yüksel, H, S., \& Mavi Var, S. (2016). Ankara University Colleges' Personnels' Healthy Life Habits and Physical Activity Consciousness Levels. Spormetre, The Journal of Ankara University Sport Sciences Faculty, 14(1), 109-119. https://doi.org/10.1501/ Sporm

Uitenbroek, D. G. (1993). Relationships between changes in health and fitness and the perception of $\begin{array}{lllll}\text { exercise. Research quarterly for exercise and } & \text { sport, 64(3), }\end{array}$ https://doi.org/10.1177/003693309303800105

Yokoyama, M., Yokoyama, T., Funazu, K., Yamashita, T., Kondo, S., Hosoai, H., Yokoyama, A., \& Nakamura, H. (2009). Associations between headache and stress, alcohol drinking, exercise, sleep, and comorbid health conditions in a Japanese population. The Journal of Headache and Pain, 10(3), 177- 185. https://doi.org/10.1007/s10194-009-0113-7 